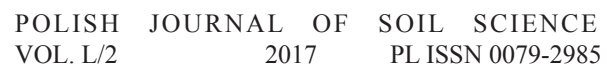

DOI: $10.17951 / \mathrm{pjss} / 2017.50 .2 .155$

JERZY TERLIKOWSKI*

\title{
RATIONAL PRODUCTIVE USE OF INORGANIC NITROGEN RESERVES RELEASED IN PERMANENT MEADOW SITUATED ON HUMIC ALLUVIAL SOIL
}

Abstract. The aim of the study was to work out a method for quantitative assessment of soil nitrogen available for grassland sward (net mineralization), released in alluvial soils in Żuławy. Quantitative assessment of the pool of released nitrogen enables improvement of $\mathrm{N}$ management in fertilization of grassland sward and may contribute to the limitation of its dispersal in the natural environment. Studies were carried out in Żuławy Elbląskie in heavy, shallow humic alluvial soil containing about $350 \mathrm{t}$ of soil organic matter and from 13 to $20 \mathrm{t}$ of total nitrogen (TN) per hectare. The study object was permanent meadow sward of different intensity of utilisation and inorganic fertilisation. The efficiency of net mineralization of soil $\mathrm{N}$ was determined with the use of indirect balance method. Łaukajtys's mini lysimetres installed on each experimental plot were used to estimate nitrogen losses in leachates. Depending on the frequency of mowing and different NPK fertilization, meadow sward took up from 80 to $170 \mathrm{~kg} \mathrm{~N}$ released due to mineralization of soil organic matter, which made up about 25 to $50 \%$ of nutrient demands of meadow sward. It was also shown that meadow sward uses from $58 \%$ to $78 \%$ of the total amount of introduced $\mathrm{N}$ for growth increment, depending on the intensity of utilization and fertilization.

Keywords: permanent meadow, alluvial soil, net mineralization of soil nitrogen

* Institute of Technology and Life Sciences, Falenty, Al. Hrabska 3, 05-090 Raszyn; Żuławy Research Centre, Elbląg, ul. Giermków 5, 82-300; e-mail: j.terlikowski@op.pl 


\section{INTRODUCTION}

Rational management of inorganic nitrogen in permanent grasslands is a basic factor, decisive for economically justified nitrogen use in fodder production and, at the same time, may limit the negative effect of agricultural production on natural environment (Sapek 2010).

Recognition of plant demands for nutrients is only one of the factors important for rational nutrient management. Meadow sward satisfies its nutrient needs from fertilization but also from natural soil resources and, in the case of nitrogen, also from biological $\mathrm{N}$ fixation and from dry and wet precipitation (Sapek and Nawalany 2006). It might be of great importance to assess the efficiency of mineralization of organic nitrogen compounds in habitats of mineral meadow soils in order to improve N management on grasslands (Sapek and Kalińska 2004).

The amount of soil nitrogen taken up by biomass of yield is termed net mineralization. This is a difference between gross mineralization and microbial immobilization, nitrogen taken up by sward and its losses to the environment (Burzyńska 2013, Terlikowski 2005).

Nitrogen mineralization consists of a set of processes leading to the formation of ammonia or ammonium-nitrogen. Establishment of inorganic nitrogen content is a result of equilibrium of two contradictory processes: mineralization and immobilization. Its level depends on the chemical composition of organic matter, mainly on the carbon to nitrogen ratio (Kobuz 1996).

Much attention has been paid recently to nitrogen management in view of threats posed by $\mathrm{N}$ dispersion in the environment. The problem of dispersion of nitrogen released during mineralization of humus is associated with the balance of soil organic matter in view of the search for efficient ways of mitigating negative effects of increased emission of greenhouse gases (Niggli et al. 2008). Estimation of the amounts of nitrogen not used by meadow sward allows, in turn, for assessing potential environmental risks and the efficiency of plant production (Terlikowski 2009).

Susceptibility of organic nitrogen compounds to mineralization is different and depends on soil and water conditions and on the rate of decomposition of each component of soil organic matter (Paul and Clark 2000). Mineralization of soil organic matter may proceed at different rates, which depend on redox potential. Mineralization of organic nitrogen in soil determines its utilization by sward and losses due to leaching of nitrates. Kobuz (1996) found that soil organic matter contains more than $90 \%$ of combined nitrogen. Its transformation may be one of important sources of inorganic nitrogen for plants. However, the process is controlled by temperature, moisture and the amount and quality of soil organic matter being a microbial substrate. According to Smith and Paul (1990), who studied the dynamics of mineralization of soil organic matter, from 95 to $380 \mathrm{~kg} \mathrm{~N} \cdot \mathrm{ha}^{-1}$ may be mineralized annually in meadow ecosystems. 
Since nitrogen is a very mobile element and left in soil after plant harvest can easily be lost due to leaching to ground water or volatilization to the atmosphere, it is important to estimate the pool of nitrogen released from soil organic matter in order to optimise fertilization of meadows with this nutrient.

The aim of this study was to elaborate a method of quantitative assessment of soil nitrogen available for meadow sward (net mineralization) released from alluvial soils in Żuławy.

\section{MATERIALS AND METHODS}

Studies were carried out in the years 2008-2011 in Helenowo on Żuławy Elbląskie. Uni-factorial field experiment situated on a meadow renovated in the year 2001 with the complete cultivation method was set up with the random block method in four repetitions according to scheme presented in Table 1.

TABLE 1. SCHEME OF EXPERIMENT IN HELENOWO

\begin{tabular}{|c|c|c|c|c|}
\hline $\begin{array}{l}\text { Kind of } \\
\text { grassland }\end{array}$ & Object & $\begin{array}{c}\text { Number } \\
\text { of cuts }\end{array}$ & Fertilization & Doses of fertilizers \\
\hline \multirow{5}{*}{$\begin{array}{l}\text { Permanent } \\
\text { meadow }\end{array}$} & 1 & 1 & 0 & \multirow{5}{*}{$\begin{array}{c}\mathrm{N}-60 \mathrm{~kg} \cdot \mathrm{ha}^{-1} \text { under regrowth; } \\
\mathrm{P}-40 \mathrm{~kg} \cdot \mathrm{ha}^{-1} \text {; } \\
\mathrm{K}-50 \mathrm{~kg} \cdot \mathrm{ha}^{-1} \text { in spring } \\
+50 \mathrm{~kg} \cdot \mathrm{ha}^{-1} \text { in the middle } \\
\text { of the growing season }\end{array}$} \\
\hline & 2 & 2 & 0 & \\
\hline & 3 & 2 & PK & \\
\hline & 4 & 3 & PK & \\
\hline & 5 & 3 & NPK & \\
\hline
\end{tabular}

Sward had a simplified botanical composition dominated by: the cock's foot (Dactylis glomerata L.) and timothy grass (Phleum pratense L.) with a small contribution of the meadow fescue (Festuca pratensis L.), couch grass (Elymus repens L.) and common meadow-grass (Poa pratensis L.). Grasses constituted about $75-85 \%$ of plant cover, dicotyledons - about $25 \%$, and legumes were present in trace amounts. Meadow was situated 0.40 a.s.l., on very heavy alluvial soil underlined by loose sand $[8 \mathrm{~F} \mathrm{bc} \cdot \mathrm{pl}]$. Humic horizon was a soil layer of $45-55 \mathrm{~cm}$ thick. There were no statistically significant differences in soil total nitrogen and carbon among studied objects; therefore, mean $\mathrm{C}: \mathrm{N}$ ratios were calculated. The ratio was 10.0 for $0-20 \mathrm{~cm}$ and $20-40 \mathrm{~cm}$ soil layers and 36.6 for 41-60 cm soil layer. Selected physical and chemical soil properties are given in Table 2. 
TABLE 2. PHYSICAL AND CHEMICAL PROPERTIES OF SOIL

\begin{tabular}{|c|c|c|c|c|c|c|}
\hline \multirow[t]{2}{*}{$\begin{array}{l}\text { Depth } \\
{[\mathrm{cm}]}\end{array}$} & \multirow{2}{*}{$\begin{array}{c}\text { Bulk } \\
\text { density } \\
{\left[\mathrm{g} \cdot \mathrm{cm}^{-3}\right]}\end{array}$} & \multirow[t]{2}{*}{$\mathrm{C}[\%]$} & \multirow[t]{2}{*}{$\begin{array}{c}\mathrm{pH} \\
{[1 \mathrm{~N} \mathrm{KCl}]}\end{array}$} & \multicolumn{3}{|c|}{$\begin{array}{c}\text { Concentration of available } \\
\text { components } \\
{\left[\mathrm{mg} \cdot \mathrm{kg}^{-1} \text { soil dry mass }\right]}\end{array}$} \\
\hline & & & & $\mathrm{P}$ & $\mathrm{K}$ & $\mathrm{Mg}$ \\
\hline \multirow{2}{*}{$0-20$} & 1.295 (Block A and B) & 4.00 & 4.88 & 42 & 411 & 50 \\
\hline & 1.269 (Block C and D) & 4.04 & 5.29 & 31 & 327 & 52 \\
\hline \multirow{2}{*}{$21-40$} & 1.315 (Block A and B) & 3.88 & 5.36 & 45 & 206 & 52 \\
\hline & 1.307 (Block C and D) & 3.95 & 5.32 & 39 & 243 & 48 \\
\hline \multirow{2}{*}{$41-60$} & 1.307 (Block A and B) & 2.75 & 6.31 & 43 & 111 & 17 \\
\hline & 1.378 (Block C and D) & 2.84 & 6.33 & 23 & 79 & 21 \\
\hline
\end{tabular}

Precipitations and temperatures for the years 2008-2011 and long-term (1971-2010) means are presented in Table 3. Sielianinov's hydro-thermal coefficient (Stachowski 2010) was used to assess thermal and pluviometric conditions.

\section{TABLE 3. METEOROLOGICAL CONDITIONS DURING THE EXPERIMENT}

\begin{tabular}{|c|c|c|c|c|c|c|c|c|c|c|c|c|c|c|}
\hline Month & I & II & III & IV & V & VI & VII & VIII & IX & $\mathrm{X}$ & XI & XII & \multicolumn{2}{|c|}{$\begin{array}{c}\text { Average }\left[{ }^{\circ} \mathrm{C}\right] \\
\text { Sum }[\mathrm{mm}] \\
\end{array}$} \\
\hline Year & & & & & & & & & & & & & IV-IX & I-XII \\
\hline \multicolumn{15}{|c|}{ Temperature $\left[{ }^{\circ} \mathrm{C}\right]$} \\
\hline $2008 * *$ & 1.3 & 3.7 & 3.8 & 8.3 & 13.0 & 17.2 & 18.4 & 18.2 & 14.3 & 8.0 & 4.5 & 1.1 & 14.9 & 9.3 \\
\hline $2009^{* *}$ & -2.0 & -0.5 & 2.6 & 10.0 & 12.5 & 15.0 & 19.1 & 18.8 & 15.1 & 15.1 & 5.9 & -1.1 & 15.1 & 8.5 \\
\hline $2010 * *$ & -7.6 & -2.0 & 3.0 & 7.7 & 11.5 & 16.4 & 21.7 & 19.8 & 13.4 & 13.4 & 4.8 & -6.4 & 15.1 & 7.4 \\
\hline $2011 * *$ & -0.9 & -5.2 & 2.5 & 13.2 & 13.0 & 17.6 & 18.6 & 18.5 & 15.0 & 15.0 & 4.2 & 3.0 & 16.0 & 9.1 \\
\hline 1971-2010* & - & - & - & 7.5 & 12.7 & 15.6 & 17.7 & 17.5 & 13.2 & - & - & - & 14.0 & - \\
\hline \multicolumn{15}{|c|}{ Precipitation [mm] } \\
\hline $2008 * *$ & 35.0 & 13.7 & 31.4 & 28.8 & 16.6 & 51.0 & 83.7 & 90.7 & 32.0 & 46.2 & 24.5 & 18.0 & 302.8 & 471.6 \\
\hline $2009 * *$ & 24.1 & 15.5 & 55.2 & 2.3 & 62.3 & 114.8 & 114.3 & 18.8 & 22.4 & 91.3 & 28.4 & 24.8 & 334.9 & 574.2 \\
\hline $2010 * *$ & 0.0 & 19.8 & 21.7 & 13.2 & 81.3 & 13.5 & 68.0 & 108.8 & 44.6 & 10.3 & 83.6 & 15.1 & 329.4 & 479.9 \\
\hline $2011 * *$ & 42.6 & 18.0 & 11.1 & 1.0 & 9.0 & 46.6 & 105.2 & 36.9 & 11.6 & 36.4 & 8.0 & 26.3 & 210.3 & 352.7 \\
\hline 1971-2010* & - & - & - & 35.3 & 54.9 & 75.3 & 83.3 & 77.8 & 68.2 & - & - & - & 394.8 & - \\
\hline \multicolumn{15}{|c|}{ Sielianinov's hydro-thermal coefficient } \\
\hline $2008 * *$ & - & - & - & 1.16 & 0.41 & 0.99 & 1.47 & 1.61 & 0.75 & 1.86 & - & - & - & - \\
\hline $2009 * *$ & - & - & - & 0.08 & 1.61 & 2.55 & 1.93 & 0.32 & 0.49 & 1.95 & - & - & - & - \\
\hline $2010 * *$ & - & - & - & 0.57 & 2.28 & 0.27 & 1.01 & 1.77 & 1.11 & 0.25 & - & - & - & - \\
\hline $2011^{* *}$ & - & - & - & 0.03 & 0.22 & 0.88 & 1.82 & 0.64 & 0.26 & 0.78 & - & - & - & - \\
\hline
\end{tabular}

Source: own work based on:

* - data from the Sea Branch of Institute for Meteorology and Water Management in Gdynia

** - data from meteorological station of Żuławy Branch of the Institute of Technology and Life Sciences in Helenowo near Elbląg.

In general, daily mean temperatures were higher compared with the longterm data. In the years 2008-2010, mean temperature for the vegetation season was higher by $1^{\circ} \mathrm{C}$ than the long-term mean. However, daily mean temperature 
for the vegetation season 2011 was higher by $2.0^{\circ} \mathrm{C}$ than the long-term mean. Sums of precipitation for vegetation seasons 2008-2011 were smaller compared with the long-term mean. In the 2008-2010 vegetation seasons, the differences amounted $15-23 \%$ and in the 2011 season, the sum of precipitation was smaller by about $46 \%$ than the long-term mean. With the use of Sielianinov's coefficient it was shown that the most favourable thermal and hydrometric conditions for the growth and development of analysed meadow were those in the year 2009.

Ground water table depth during the study period varied from $35-40 \mathrm{~cm}$ in spring (before vegetation) and declined subsequently from May to the end of vegetation to $150-155 \mathrm{~cm}$.

Szyłowa’s mini lysimeter modified by Łaułkajtys was used to collect leakages of soil solutions infiltrating down the soil profile for quantitative and qualitative analyses. Colorimetric method was used to determine the content of inorganic $\mathrm{N}$ forms $\left(\mathrm{N}-\mathrm{NO}_{3}\right.$ and $\left.\mathrm{N}-\mathrm{NH}_{4}\right)$ in soil (after extraction with $1 \% \mathrm{~K}_{2} \mathrm{SO}_{4}$ ) and in water leakages. Total nitrogen in soil and plants was determined with the Kjeldahl method.

Available forms of phosphorus and potassium in soil were determined with the Egner-Riehm method and of magnesium - with Schachtschabel's method following AAS records. Carbon in soil was determined with the Tiurin method and $\mathrm{pH}$ - potentiometrically in $1 \mathrm{M} \mathrm{KCl}$.

Indirect balance method was used for quantitative estimation of the efficiency of net mineralisation of soil nitrogen. The balance involved:

1) incomes:

- the content of soil inorganic $\mathrm{N}$ in spring before growing season,

- nitrogen from fertilisers,

- biologically fixed nitrogen (Sapek 2006),

- nitrogen from wet and dry precipitation (Raport WIOŚ Olsztyn 2014),

2) losses:

- nitrogen removed with yield,

- nitrogen in leachates percolating in soil out of the rhizosphere during the growing season,

- inorganic $\mathrm{N}$ in soil after the end of the growing season.

Despite many studies and experiments, no direct method was elaborated to determine soil nitrogen, which is transformed into inorganic forms taken up by grassland sward (Okruszko 1991, Terlikowski 2005). Indirect balance method allows, however, for estimating only that part of nitrogen released from organic matter, which was taken up by sward and incorporated into biomass of utilized yield (the so-called net mineralization). Therefore, the method may have significant economic importance and should be considered when calculating doses of nitrogen fertilization. 


\section{RESULTS AND DISCUSSION}

Measurements of the amounts of leakages of water infiltrating below the rhizosphere and collected in mini lysimeters started in October 2007. Results are presented in Table 4.

TABLE 4. AMOUNT OF LEAKAGES OF INFILTRATED WATER $\left[\mathrm{M}^{3 \cdot} \mathrm{HA}^{-1}\right]$, HELENOWO 2007-2012

\begin{tabular}{cccccc}
\hline Object & 1 & 2 & 3 & 4 & 5 \\
\hline $\begin{array}{c}\text { Non-growing period } \\
\text { from 16.XI.2007 till 7.IV.2008 }\end{array}$ & 735 & 753 & 721 & 782 & 765 \\
\hline $\begin{array}{c}\text { Growing period } \\
\text { from 17.IV.2008 till 1.XII.2008 }\end{array}$ & 298 & 246 & 223 & 294 & 123 \\
\hline $\begin{array}{c}\text { Non-growing period } \\
\text { from 27.II.2009 till 29.IV.2009 }\end{array}$ & 400 & 516 & 569 & 530 & 555 \\
\hline $\begin{array}{c}\text { Growing period } \\
\text { from 29.IV.2009 till 09.XI.2009 }\end{array}$ & 87 & 140 & 111 & 123 & 139 \\
\hline $\begin{array}{c}\text { Non-growing period } \\
\text { from 10.XII.2009 till 24.III.2010 }\end{array}$ & 106 & 133 & 137 & 165 & 152 \\
\hline $\begin{array}{c}\text { Growing period } \\
\text { from 28.V.2010 till 08.X.2010 }\end{array}$ & 37 & 38 & 60 & 73 & 37 \\
\hline $\begin{array}{c}\text { Non-growing period } \\
\text { from 8.X.2010 till 22.III.2011 }\end{array}$ & 112 & 84 & 120 & 137 & 149 \\
\hline $\begin{array}{c}\text { Growing period } \\
\text { from 22.III.2011 till 03.XI.2011 }\end{array}$ & 147 & 128 & 139 & 147 & 116 \\
\hline $\begin{array}{c}\text { Non-growing period } \\
\text { from 8.X.2011 till 22.III.2012 }\end{array}$ & 118 & 121 & 149 & 151 & 150 \\
\hline $\begin{array}{c}\text { Growing period } \\
\text { from 22.III.2012 till 03.XI.2012 }\end{array}$ & 147 & 150 & 50 & 148 & 150 \\
\hline
\end{tabular}

Leakages were several times larger outside than during the growing season. This difference might have a significant effect on the dispersal of inorganic nitrogen loads to ground waters.

The amount of inorganic nitrogen loads lost to ground waters is presented in Table 5. Chemical analysis of water from leakages included both inorganic forms: $\mathrm{N}_{-} \mathrm{NO}_{3}$ and $\mathrm{N}-\mathrm{NH}_{4}$. It was noted that in the growing seasons 2008-2012, much smaller loads were delivered to ground waters than outside the growing seasons. Substantial differences in nitrogen loads percolating down the soil profile with infiltrating water were found among studied plots of different frequency of mowing and fertilizing. The largest losses of inorganic $\mathrm{N}$ occurred from under plots mown 3 times and fertilized with complete dose of NPK $\left(180 \mathrm{~kg} \mathrm{~N} \cdot \mathrm{ha}^{-1}\right)$. 
TABLE 5. LOADS OF MINERAL NITROGEN $\left(\mathrm{N}-\mathrm{NO}_{3}+\mathrm{N}-\mathrm{NH}_{4}\right)$ IN LEAKING WATER OUT OF THE SWARD ROOT ZONE, HELENOWO 2007-2012

\begin{tabular}{cccccc}
\hline \multirow{2}{*}{ Measurement of leasing water } & \multicolumn{7}{c}{ Object } \\
\cline { 2 - 6 } & 1 & 2 & 3 & 4 & 5 \\
\hline from 16.XI.2007 till 17.IV.2008 & 2.1 & 2.3 & 2.7 & 3.3 & 3.4 \\
\hline from 07.IV.2008 till 10.XI.2008 & 0.6 & 1.6 & 2.0 & 1.1 & 0.9 \\
\hline from 11.XI.2008 till 28.IV.2009 & 204 & 242 & 196 & 131 & 268 \\
\hline from 29.IV.2009 till 09.XI.2009 & 21 & 5 & 9 & 2 & 8 \\
\hline from 10.XI.2009 till 24.III.2010 & 94 & 50 & 54 & 71 & 196 \\
\hline from 25.III.2010 till 08.X.2010 & 11 & 17 & 10 & 47 & 30 \\
\hline from 09.X.2010 till 22.III.2011 & 15 & 15 & 63 & 76 & 115 \\
\hline from 23.III.2011 till 03.XI.2011 & 25 & 82 & 64 & 65 & 83 \\
\hline from 04.XI.2011 till 22.III.2012 & 91 & 73 & 171 & 177 & 203 \\
\hline from 23.III.2012 till 03.XI.2012 & 32 & 75 & 83 & 126 & 131 \\
\hline Mean amount of loads of N \\
from growing periods & & & & & \\
from non-growing periods & $\mathbf{1 8}$ & $\mathbf{3 6}$ & $\mathbf{3 4}$ & $\mathbf{4 8}$ & $\mathbf{5 1}$ \\
\hline
\end{tabular}

Original incubation samplers were constructed (Sapek and Kalińska 2004) to determine differential mineralization of soil organic matter. Studies were made in incubated and in situ isolated soil samples and, for comparison, in soil taken from under vegetation. Adopted length of the sampler depended on the thickness of humic soil horizon. Samplers were thus divided into three equal incubation levels: 0-20, 21-40 and 41-60 cm. Differential incubation of soil was performed in spring, summer and autumn and outside the growing season. During vegetation, soil samples were incubated for two weeks. Results of differential mineralization are presented in Table 6.

TABLE 6. DIFFERENTIAL MINERALISATION OF SOIL ORGANIC MATTER $\left[\mathrm{KG} \mathrm{N}_{\mathrm{MIN}} \cdot \mathrm{HA}^{-1}\right.$ ], HELENOWO 2007-2012

\begin{tabular}{cccccc}
\hline Investigation period & \multicolumn{5}{c}{ Object } \\
\cline { 2 - 6 } Non-growing period \\
from 16.XI.2007 till 7.IV.2008 & 1 & 2 & 3 & 4 & 5 \\
\hline $\begin{array}{c}\text { Growing period } \\
\text { from 3-4.IV.2008 till 21.X and 04.XI.2008 }\end{array}$ & 4 & 10 & -3 & 18 & 58 \\
\hline $\begin{array}{c}\text { Non-growing period } \\
\text { from 21.X.2008 till 6.IV and 9.IV.2009 }\end{array}$ & 6 & 22 & 38 & 20 & 11 \\
\hline $\begin{array}{c}\text { Growing period } \\
\text { from 6.IV and 9. IV.2009 till 26.X and 03.XI.2009 }\end{array}$ & 25 & 43 & 40 & 12 & 63 \\
\hline $\begin{array}{c}\text { Non-growing period } \\
\text { from 03.XI. 2009 till 6.IV. and 9. IV. 2010 }\end{array}$ & 51 & 76 & 78 & 73 & 70 \\
\hline $\begin{array}{c}\text { Growing period } \\
\text { from 9.IV.2010 till 03.XI.2010 }\end{array}$ & -5 & 5 & 17 & -9 & -35 \\
\hline
\end{tabular}




\begin{tabular}{cccccc}
\hline Investigation period & \multicolumn{5}{c}{ Object } \\
\cline { 2 - 6 } & 1 & 2 & 3 & 4 & 5 \\
\hline $\begin{array}{c}\text { Non-growing period } \\
\text { from 8.X.2010 till 22.III.2011 }\end{array}$ & 24 & 48 & 57 & 41 & 42 \\
\hline $\begin{array}{c}\text { Growing period } \\
\text { from 22.III.2011 till 03.XI.2011 }\end{array}$ & 56 & 22 & 16 & 42 & 89 \\
\hline $\begin{array}{c}\text { Non-growing period } \\
\text { from 17.X.2011 till 11.VI.2012 }\end{array}$ & 20 & 70 & 76 & 46 & 53 \\
\hline $\begin{array}{c}\text { Growing period } \\
\text { from 11.IV.2012 till 20.IX.2012 }\end{array}$ & 43 & 0 & 53 & 30 & 54 \\
\hline
\end{tabular}

Nitrogen balances presented in Tables 7-10 showed that the amount of soil nitrogen taken up by sward depended on meteorological conditions, frequency of mowing and applied fertilization. Results of $\mathrm{N}$ balance were assessed for each study year of the period 2008-2011.

Mean annual uptake of soil $\mathrm{N}$ by sward mown once and not fertilized with mineral fertilizers was $80 \mathrm{~kg} \mathrm{~N}$ per ha. Increasing frequency of mowing to two cuts (still without NPK fertilization) improved the utilization of soil $\mathrm{N}$ since sward took up about $150 \mathrm{~kg} \cdot \mathrm{ha}^{-1} \cdot \mathrm{year}^{-1}$. PK fertilization further improved nitrogen uptake from soil to about $170 \mathrm{~kg} \cdot \mathrm{ha}^{-1} \cdot \mathrm{year}^{-1}$, while sward mown three times a year and fertilized with PK took up about $160 \mathrm{~kg} \cdot \mathrm{ha}^{-1} \cdot \mathrm{year}^{-1}$. Complete fertilization and triple mowing decreased the uptake of soil $\mathrm{N}$ to about $104 \mathrm{~kg} \mathrm{~N}_{\text {soil }} \cdot \mathrm{ha}^{-1} \cdot \mathrm{y}^{-1}$. Thus, most rational utilization of soil $\mathrm{N}$ in a permanent meadow situated on very heavy humic alluvial soil might be obtained at double or triple mowing and fertilization limited to PK only. Nitrogen dose of $60 \mathrm{~kg} \mathrm{~N} \cdot \mathrm{ha}^{-1}$ under cut seemed to be excessive in relation to plant demands for nutrients under experimental habitat conditions. The efficiency of net mineralization, depending on thermal and pluviometric conditions, may be assessed at $100-150 \mathrm{~kg} \mathrm{~N} \cdot \mathrm{ha}^{-1} \cdot \mathrm{year}^{-1}$.

TABLE 7. BALANCE OF MINERAL NITROGEN ON A PERMANENT MEADOW IN 2008

\begin{tabular}{cccccc}
\hline Element of balance & \multicolumn{5}{c}{ Object } \\
\cline { 2 - 6 } & 1 & 2 & 3 & 4 & 5 \\
\hline Input: & & & & & \\
\hline - spring retention (1) & 64 & 78 & 60 & 65 & 62 \\
\hline - mineral fertilizers (2) & - & - & - & - & 180 \\
\hline - N from precipitations (3) & 10 & 10 & 10 & 10 & 10 \\
\hline - biological N (4) & 20 & 20 & 20 & 20 & 20 \\
\hline Input together: (5) & $\mathbf{9 4}$ & $\mathbf{1 0 8}$ & $\mathbf{9 0}$ & $\mathbf{9 5}$ & $\mathbf{2 7 2}$ \\
\hline Output: & & & & & \\
\hline - with yield (6) & 122 & 221 & 269 & 254 & 352 \\
\hline - autumn retention (7) & 60 & 54 & 50 & 63 & 60 \\
\hline - N in leachates (8) & 1 & 2 & 2 & 1 & 1 \\
\hline Output together: (9) & $\mathbf{1 8 3}$ & $\mathbf{2 7 7}$ & $\mathbf{3 2 1}$ & $\mathbf{3 1 8}$ & $\mathbf{4 1 3}$ \\
\hline
\end{tabular}




\begin{tabular}{cccccc}
\hline \multirow{2}{*}{ Element of balance } & \multicolumn{5}{c}{ Object } \\
\cline { 2 - 6 } & 1 & 2 & 3 & 4 & 5 \\
\hline $\mathrm{N}_{\text {soi }}$ uptaken by sward [6-(2+3+4)] & 92 & 191 & 239 & 224 & 142 \\
\hline - N from differential incubation & 4 & 10 & -3 & 18 & 58 \\
\hline $\begin{array}{c}\text { Relation [in \%] of N uptaken by sward to sum } \\
\text { of N output [(6×100):9] }\end{array}$ & 67 & 80 & 84 & 80 & 85 \\
\hline
\end{tabular}

\section{TABLE 8. BALANCE OF MINERAL NITROGEN ON A PERMANENT} MEADOW IN 2009

\begin{tabular}{cccccc}
\hline Element of balance & \multicolumn{5}{c}{ Object } \\
\cline { 2 - 6 } Input: & 1 & 2 & 3 & 4 & 5 \\
\hline - spring retention (1) & 66 & 80 & 58 & 70 & 65 \\
\hline - mineral fertilizers (2) & - & - & - & - & 180 \\
\hline - N from precipitations (3) & 10 & 10 & 10 & 10 & 10 \\
\hline - biological N (4) & 20 & 20 & 20 & 20 & 20 \\
\hline Input together: (5) & $\mathbf{9 6}$ & $\mathbf{1 1 0}$ & $\mathbf{8 8}$ & $\mathbf{1 0 0}$ & $\mathbf{2 7 5}$ \\
\hline Output: & & & & & \\
\hline - with yield (6) & 181 & 238 & 261 & 192 & 334 \\
\hline - autumn retention (7) & 47 & 61 & 57 & 44 & 47 \\
\hline - N in leachates (8) & 21 & 5 & 9 & 2 & 8 \\
\hline Output together: (9) & $\mathbf{2 4 9}$ & $\mathbf{3 0 4}$ & $\mathbf{3 2 7}$ & $\mathbf{2 3 8}$ & $\mathbf{3 9 9}$ \\
\hline $\mathrm{N}_{\text {soil }}$ uptaken by sward [6-(2+3+4)] & 151 & 208 & 231 & 162 & 134 \\
\hline - N from differential incubation & 25 & 43 & 40 & 12 & 63 \\
\hline $\begin{array}{c}\text { Relation [in } \% \text { of } N \text { uptaken by sward to sum } \\
\text { of N output [(6×100):9] }\end{array}$ & 72 & 78 & 80 & 81 & 84 \\
\hline
\end{tabular}

TABLE 9. BALANCE OF MINERAL NITROGEN ON A PERMANENT MEADOW IN 2010

\begin{tabular}{|c|c|c|c|c|c|}
\hline \multirow{2}{*}{ Element of balance } & \multicolumn{5}{|c|}{ Object } \\
\hline & 1 & 2 & 3 & 4 & 5 \\
\hline \multicolumn{6}{|l|}{ Input: } \\
\hline - spring retention (1) & 64 & 77 & 66 & 74 & 67 \\
\hline - mineral fertilizers (2) & - & - & - & - & 180 \\
\hline - $\mathrm{N}$ from precipitations (3) & 10 & 10 & 10 & 10 & 10 \\
\hline - biological N (4) & 20 & 20 & 20 & 20 & 20 \\
\hline Input together: (5) & 94 & 107 & 96 & 104 & 277 \\
\hline \multicolumn{6}{|l|}{ Output: } \\
\hline - with yield (6) & 61 & 135 & 132 & 153 & 277 \\
\hline - autumn retention (7) & 67 & 66 & 61 & 63 & 63 \\
\hline - N in leachates (8) & 11 & 17 & 10 & 47 & 30 \\
\hline Output together: (9) & 139 & 218 & 203 & 263 & 370 \\
\hline $\mathrm{N}_{\text {soil }}$ uptaken by sward $[6-(2+3+4)]$ & 31 & 105 & 102 & 123 & 67 \\
\hline - $\mathrm{N}$ from differential incubation & -5 & 5 & 17 & -9 & -35 \\
\hline $\begin{array}{c}\text { Relation [in \%] of } N \text { uptaken by sward to sum } \\
\text { of } N \text { output }[(6 \times 100): 9]\end{array}$ & 44 & 62 & 65 & 58 & 75 \\
\hline
\end{tabular}


TABLE 10. BALANCE OF MINERAL NITROGEN ON A PERMANENT MEADOW IN 2011

\begin{tabular}{cccccc}
\hline Element of balance & \multicolumn{5}{c}{ Object } \\
\cline { 2 - 6 } & 1 & 2 & 3 & 4 & 5 \\
\hline Input: & & & & & \\
\hline - spring retention (1) & 67 & 76 & 72 & 74 & 67 \\
\hline - mineral fertilizers (2) & - & - & - & - & 180 \\
\hline - N from precipitations (3) & 10 & 10 & 10 & 10 & 10 \\
\hline - biological N (4) & 20 & 20 & 20 & 20 & 20 \\
\hline Input together: (5) & $\mathbf{9 7}$ & $\mathbf{1 0 6}$ & $\mathbf{1 0 2}$ & $\mathbf{1 0 4}$ & $\mathbf{2 7 7}$ \\
\hline Output: & & & & & \\
\hline - with yield (6) & 81 & 125 & 133 & 165 & 281 \\
\hline - autumn retention (7) & 64 & 68 & 54 & 69 & 60 \\
\hline - N in leachates (8) & 25 & 82 & 64 & 65 & 83 \\
\hline Output together: (9) & $\mathbf{1 7 0}$ & $\mathbf{2 7 5}$ & $\mathbf{2 5 1}$ & $\mathbf{2 9 9}$ & $\mathbf{4 2 4}$ \\
\hline $\mathrm{N}_{\text {soil }}$ uptaken by sward [6-(2+3+4)] & 51 & 95 & 103 & 135 & 71 \\
\hline - N from differential incubation & 56 & 22 & 16 & 42 & 89 \\
\hline Relation [in $\%$ of $N$ uptaken by sward to sum & 48 & 45 & 53 & 55 & 66 \\
\hline of N output [(6×100):9] & & & & &
\end{tabular}

Application of the balance method to compare inorganic nitrogen taken up by yield of meadow sward with the total output of inorganic nitrogen may bring remarkable results. The nitrogen uptake to output ratio in extensive meadow use (one cut, no fertilization) was $58 \%$. The same ratio for a meadow mown twice was $66 \%$ and application of PK fertilizers increased the ratio to $71 \%$. In a meadow mown three times and fertilized with PK the ratio was similar to the latter. The uptake to output ratio was highest (78\%) in a meadow mown three times a season and fertilized with NPK.

Obtained results indicate that, considering nitrogen input from natural sources, supplementing dose of mineral $\mathrm{N}$ fertilization should not exceed $100 \mathrm{~kg}$ $\mathrm{N} \cdot h \mathrm{~h}^{-1} \cdot \mathrm{y}^{-1}$ for very heavy, shallow humic alluvial soils.

The relationships between total nitrogen content in soil profile and inorganic nitrogen taken up by meadow sward were also compared and assessed. Compared were the results obtained in the years 2009-2011 (Table 11). The proportion of utilised inorganic $\mathrm{N}$ to total $\mathrm{N}$ in soil profile depended on the frequency of mowing and fertilization and on thermal and pluviometric conditions. In meadows mown two or three times without $\mathrm{N}$ fertilization (plots 2, 3 and 4) nitrogen taken up by sward constituted 0.57 to $0.72 \%$ of total $\mathrm{N}$ in dry conditions during the growing season. In favourable meteorological conditions percent of $\mathrm{N}$ taken up by plants varied from $0.90 \%$ to as much as $1.35 \%$ of total $\mathrm{N}$. 
TABLE 11. AMOUNT AND RELATION [IN \%] OF N ${ }_{\text {MIN }}$ UPTAKEN BY SWARD TO ITS CONTENT IN SOIL PROFILE DEPENDED ON CUT FREQUENCY AND FERTILIZATION

\begin{tabular}{|c|c|c|c|c|c|}
\hline & \multicolumn{5}{|c|}{2009} \\
\hline Object & 1 & 2 & 3 & 4 & 5 \\
\hline $\mathrm{N}_{\text {total }}$ in soil $\left[\mathrm{kg} \cdot \mathrm{ha}^{-1}\right]$ & 17500 & 16980 & 17050 & 17950 & 16150 \\
\hline $\mathrm{N}_{\text {min }}$ uptaken by sward from soil & 151 & 208 & 231 & 162 & 134 \\
\hline \multirow[t]{2}{*}{$\% \mathrm{~N}_{\text {total }}$ uptaken by sward } & 0.86 & 1.22 & 1.35 & 0.90 & 0.83 \\
\hline & \multicolumn{5}{|c|}{2010} \\
\hline $\mathrm{N}_{\text {total }}$ in soil $\left[\mathrm{kg} \cdot \mathrm{ha}^{-1}\right]$ & 18100 & 16300 & 17000 & 19200 & 14400 \\
\hline $\mathrm{N}_{\text {min }}$ uptaken by sward from soil & 31 & 105 & 102 & 123 & 67 \\
\hline \multirow[t]{2}{*}{$\% \mathrm{~N}_{\text {total }}$ uptaken by sward } & 0.17 & 0.64 & 0.60 & 0.64 & 0.47 \\
\hline & \multicolumn{5}{|c|}{2011} \\
\hline $\mathrm{N}_{\text {total }}$ in soil $\left[\mathrm{kg} \cdot \mathrm{ha}^{-1}\right]$ & 17800 & 16700 & 17100 & 18700 & 16400 \\
\hline $\mathrm{N}_{\min }$ uptaken by sward from soil & 51 & 95 & 103 & 135 & 71 \\
\hline$\% \mathrm{~N}_{\text {total }}$ uptaken by sward & 0.29 & 0.57 & 0.60 & 0.72 & 0.43 \\
\hline
\end{tabular}

Obtained results suggest that knowing the content of total nitrogen in organic matter of humic alluvial soils, one may approximately assess the amount of inorganic nitrogen released during the growing season and available for meadow sward.

\section{CONCLUSIONS}

To sum up 4-year-long studies with the use of "balance in the field" method on inorganic nitrogen in a permanent meadow grown on Żuławy alluvial soils, one may draw the following conclusions:

1. The demands of meadow sward for nitrogen in heavy shallow humic alluvial soils might be satisfied by soil nitrogen in amounts of about $100 \mathrm{~kg} \mathrm{~N}$. ha ${ }^{-1} \cdot \mathrm{y}^{-1}$.

2. The "balance in the field" method was proved to be useful for quantitative assessment of inorganic nitrogen released during mineralization of soil organic matter, taken up by meadow swards and incorporated into biomass.

3. Applied method may be a tool in controlling nitrogen management in grassland habitats situated on mineral soils and in elaborating new rules of nitrogen management with the consideration of dynamic processes of organic matter transformation in mineral meadow soils. 


\section{REFERENCES}

[1] Burzyńska, I., 2013. Migration of inorganic components and organic carbon to groundwaters at different use of meadows on minerals soils (in Polish). Woda - Środowisko - Obszary Wiejskie. Rozprawy naukowe i monografie nr 35, Wyd. Falenty, pp. 92.

[2] Kobuz, J., 1996. Role of microorganisms in nitrogen transformation in soil (in Polish). Zesz. Probl. Post. Nauk Roln., 440: 151-173.

[3] Niggli, U, Schmid, H., Fliessbach, A., 2008. Farming and Climate Change. Int. Trade Centre (ITC) Press, Geneva, Switzerland.

[4] Okruszko, H., 1991. Principles of peat soils fertilization (in Polish). In: Gospodarowanie na glebach torfowych w świetle 40-letniej działalności Zakładu Doświadczalnego Biebrza. Bibl. Wiad. IMUZ 77, pp. 87-103.

[5] Paul, E.A., Clark, F.E., 2000. Microbiology and biochemistry of waters. Wyd. UMCS, Lublin, pp. 400.

[6] Raport WIOŚ Olsztyn 2014.

[7] Sapek, B., Kalińska, D., 2004. Mineralization of soil organic nitrogen compounds in the light of long-term grassland experiments in IMUZ (in Polish). Woda - Środowisko - Obszary Wiejskie, 4, 1 (10): 183-200.

[8] Sapek, A., 2006. Share of agriculture in water pollution with fertilizers (in Polish). Zesz. Edukac. Nr 1. Wydawn. IMUZ. Falenty, pp. 9-33.

[9] Sapek, A., Nawalany, P., 2006. The loads of nutrients deposited with atmospheric precipitation on earth surface, an ex ample of experimental Fields in Falenty (in Polish). Woda - Środowisko - Obszary Wiejskie, 6, (17): 23-27.

[10] Sapek, B., 2010. Nitrogen and phosphorus release from soil organic matter (in Polish). Woda - Środowisko - Obszary Wiejskie, 10, 3 (31): 229-256.

[11] Smith, J.L., Paul, E.A., 1990. The significance of soil microbial biomass estimations. Soil Biochem., 6, 357-392.

[12] Stachowski, P., 2010. Assessment of meteorological droughts on the postmining areas in the Konin region (in Polish). Rocznik Ochrony Środowiska, 12, 587-606.

[13] Terlikowski, J., 2005. Identification of the environment threats coming from the flauty nitrogen management on the temporary dry meadow dominated with Poa pratensis and Alopecurus pratensis situated on moorshy soil. Zesz. Probl. Post., 505, 477-484.

[14] Terlikowski, J., 2009. Nitrogen management on permanent meadow in humus alluvial soil conditions in the Żuławy region (in Polish). ZPPN Rol., 538, 299-306. 